\title{
PROGRESS IN COKE RESEARCH IN GREAT BRITAIN
}

\begin{abstract}
$\mathrm{A}^{\mathrm{N}}$
$\mathrm{N}$ established annual event is the joint meeting of the Coke Oven Managers' Association, the Institution of Gas Engineers and the British Coke Research Association. These three institutions cover the technical interest of the carbonizing industries in all its facets. This annual gathering has become noteworthy for the fact that some matter of absorbing interest is discussed at the meetings.

It will be recalled that in the autumn of 1958 the Duke of Edinburgh opened the new Coke Research Centre of the British Coke Research Association at Chesterfield. A special feature of this research station is that it contains, besides chemical and physical laboratories, a large workshop laboratory for pilot-scale plant, an excellent information centre, and a full-scale plant for making coke and its byproducts. This last feature was a bold venture, which had been in the minds of the practical men of the industry for upwards of a decade.
\end{abstract}

At this year's tripartite meeting, held recently, the director of the Research Association, Mr. G. W. Lee, gave an encouraging account of the work that had been carried out during its first year at the Coke Research Centre. Naturally, everyone was interested to hear how the full-scale plant had operated in practice, for the coke-oven manager knows full well the teething troubles that may be expected to be encountered in such an undertaking. Mr. Lee was able to unfold a story of quite substantial success.

The coke oven is to be used for producing sufficient coke to enable performance trials to be made of the resultant cokes in production blast furnaces. One cannot use less than a hundred tons of fuel for trial on an industrial unit of such magnitude. There is also a by-product plant to deal with the collection of tar and other products distilled from the carbonizing coal in the oven. To overcome all the teething troubles successfully in the coldest period of the year when there was $17^{\circ} \mathrm{F}$. of frost-and incidentally seventeen coke braziers required-was no mean achievement. To train also the composite team of operators, having both technical ability and practical experience of plant operation, to run the plant had been a problem in human relations. It has to be remembered that the plant was quite unique, and the carbonizing of each charge of coal a huge scientific experiment calling for accurate instrumentation, measurement of numerous values and precise analysis.
In the upshot, the standard of repeatability of yields achieved was good, and in the final runs reported 'very good', in Mr. Lee's modest claims ; we should say, in such demanding conditions, excellent.

Perhaps the most satisfactory outcome of these trials was to prove that the results of full-scale trials confirmed the usefulness of trials in smaller experimental ovens, a range of which the Association has for long been using. Such a situation makes for accelerated progress in the matter of producing still better qualities of coke from coals of diminishing suitability for the purpose, as the reserves of coking coal of good quality become depleted.

The Coke Research Association has established, as have other research associations in Britain, a world-wide reputation for the quality of its research. In the new Research Station the equipment and the staff are such that the good work can be continued at an accelerated pace. 40 per cent of its research effort is devoted to improvement in the quality and yield of coke, and 11 per cent to the thermal behaviou. of coal and the fissuring of coke. The remainder is concerned with a wide range of fundamental and applied studies that the future welfare of the industry demands.

The layman is rightly concerned about the pollution of the air and of the rivers which industrialization carries in its train. These subjects have not been overlooked. The effluent problem in the coking industry has many features in common with that of the gas industry, and accordingly these industries have joined forces in tackling the water pollution problems that arise from their activities. The Coke Research Association is supporting both financially and technically the work of the Joint Research Committee and the University of Leeds through its Ammonia Effluents Sub-committeo.

As regards the field of atmospheric pollution, investigations of the Coke Research Centre have included preliminary studies of the chemical and physical nature of the smoke emitted from a coke oven. Naturally, problems of suppression are also being studied.

All these matters that concern the future prosperity of the coal industry contain reassuring features of particular interest to those enlightened sections of the British public which already recognize that the future of coal must depend upon the technological effort put into its utilization.

\section{SOIL SALINITY COURSE IN TUNISIA}

F OLLOWING an invitation of the Government of the Republic of Tunisia and with its sponsorship, Unesco's Middle East Science Co-operation Office organized a Regional Training Course on Diagnosis, Improvement and Management of Salt-affected Soils as a part of the Arid Zone Project. The course was held in Tunis during September 7-October 3, 1959. It consisted of one week of lectures, followed by two weeks of laboratory work and a field trip to the arid regions and saline soils in Tunisia.

The chemical aspects were treated by Dr. A. D. Ayers, formerly with the U.S. Salinity Laboratory, Riverside, California, now with the Agricultural Research Service U.S. Department of Agriculture, Rome; the geological and pedological aspects by Prof. G. Aubert, Institute of Tropical Soil Investiga- 